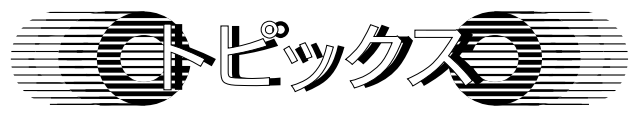

\section{タンパク質合成抑制因子RelEと その調節の構造基盤}

九州大学大学院農学研究院生物機能科学部門 木村 誠

\section{1. はじめに}

大腸菌に代表される真正細菌は，環境ストレス条件 下でDNA複製反応やタンパク質合成反応を抑制し自ら の増殖を抑える調節因子・トキシンノアンチトキシン システム※（TA システム）をもっている ${ }^{1)}$.

$\mathrm{TA}$ システムの発見は 25 年前に遡る. Ogura と Hiraga は大腸菌F-プラスミド上の遺伝子群が大腸菌の増殖を

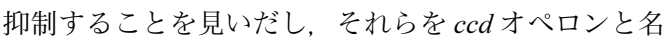

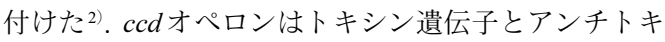
シン遺伝子からなり, F-プラスミドが大腸菌内に存在 すれば，その遺伝子産物であるトキシンとアンチトキ シンは複合体を形成し，トキシンの毒性は抑制されて いる. しかし，F-プラスミドが大腸菌の分裂過程で消 失した際には, アンチトキシンが細胞内プロテアーゼ により分解され，遊離したトキシンがジャイレースに 結合することにより大腸菌のDNA複製反応を阻害する. その結果, 大腸菌の生育が抑制される ${ }^{3)}$. すなわち, TA システムはF-プラスミドが大腸菌内での増殖を維持す るために獲得した分子装置と考えられた，その後，多

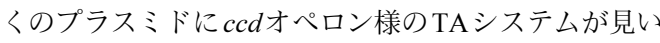
だされたが, 分子生物学の研究対象にはならなかった.

ところが, 1993 年, TA システムが大腸菌染色体上に も存在することが見いだされ4), これらのオペロンがさ まざまな環境ストレスに対応して大腸菌のDNA複製や タンパク質合成反応を調節していることが明らかになっ た.したがって, 染色体上の TA システムは真正細菌の アポトーシス様の現象にかかわる分子として考えられ, その分子生物学的研究が展開されてきた. 最近, 6 種の 大腸菌 TA システム (relBE, mazEF, $\operatorname{chpB}$, dinJ-yafQ, yoeB-yefM, yaf $N$-yafO) のうち, mazEF と yoeB-yefMの
トキシン MazF と YeoB が mRNA を切断する RNase (mRNA interferase) であることが明らかにされるとと もに ${ }^{5), 6)}$ ，それらのトキシン - アンチトキシン複合体 (MazE-MazF と YoeB-YefM) の結晶構造が報告されて (る ${ }^{7), 8)}$.

大腸菌 $\mathrm{TA}$ システムの 1 つである relBE は遺伝子 relB と relE から構成され, relE は細胞毒であるトキシン (RelE: $11 \mathrm{kDa})$ を, relB は RelEの阻害タンパク質であ るアンチトキシン（RelB: $9 \mathrm{kDa}$ )をコードしている

$(\text { Fig. 1 })^{9)}$. 通常の生育条件下では, アンチトキシン RelB はトキシン RelE と複合体（RelB-RelE）を形成するこ とにより RelEの毒性を抑制している ${ }^{10)}$. また, RelB お よびRelB-RelE複合体は relBEオペロン上流のプロモー ターに結合し, 自らの転写を負に制御するリプレッサー としても機能している ${ }^{11)}$. すなわち, RelEの毒性は転 写レベルと翻訳後レベルで抑制されている. ところが, アミノ酸欠乏条件下ではLonなどの細胞内プロテアー ゼが活性化され，プロテアーゼに対して感受性の強い RelBのみが特異的に分解されることにより RelEが活性 化される. その結果, RelEの活性によりタンパク質合 成反応が抑制される。

RelEの活性に関しては長く不明であったが, 2003年, PedersenらはRelEが翻訳過程のmRNAをリボソームの A-部位で特異的に切断することを見いだし， RelEは mRNA interferase である MazF やYoeB と異なり, リボ ソーム依存性 RNase であることを提唱した (Fig. 1) ${ }^{12)}$. 一方, Hayes と Sauer は翻訳過程でリボソームが mRNA 上で帯った際に, リボソームが mRNAを切断すること を見いだした ${ }^{13)}$.このことから, RelEはリボソームに 結合することにより, リボソームに内在しているRNase 活性を増強する因子であると提唱している研究グルー プもある1).このように, relBEを介したタンパク質合 成抑制機構に関しては未解明であり, RelB と RelEの高 次構造情報もまたれていた。

われわれは超好熱古細菌 (Pyrococcus horikoshii OT3) タンパク質の高次構造に関する研究過程で, 超好熱古 細菌ゲノム中にrelBE相同遺伝子を見いだした. そこで, RelB と RelEの高次構造情報を提供するために, それら の大腸菌内での共発現後, 組み換えタンパク質複合体 (aRelB-aRelE) を分離精製した. さらに, 精製したaRelBaRelE複合体の結晶化に成功し, その結晶構造を多波長 異常分散法により $2.3 \AA$ の分解能で決定した ${ }^{14)}$. 本稿で は, 超好熱古細菌由来 $\mathrm{aRelB}-\mathrm{aRelE}$ 複合体の結晶構造を

\title{
Protein Synthesis Suppressor RelE and Structural Basis for Its Regulation
} Makoto KIMURA

Department of Bioscience and Biotechnology, Faculty of Agriculture, Graduate School, Kyushu University 


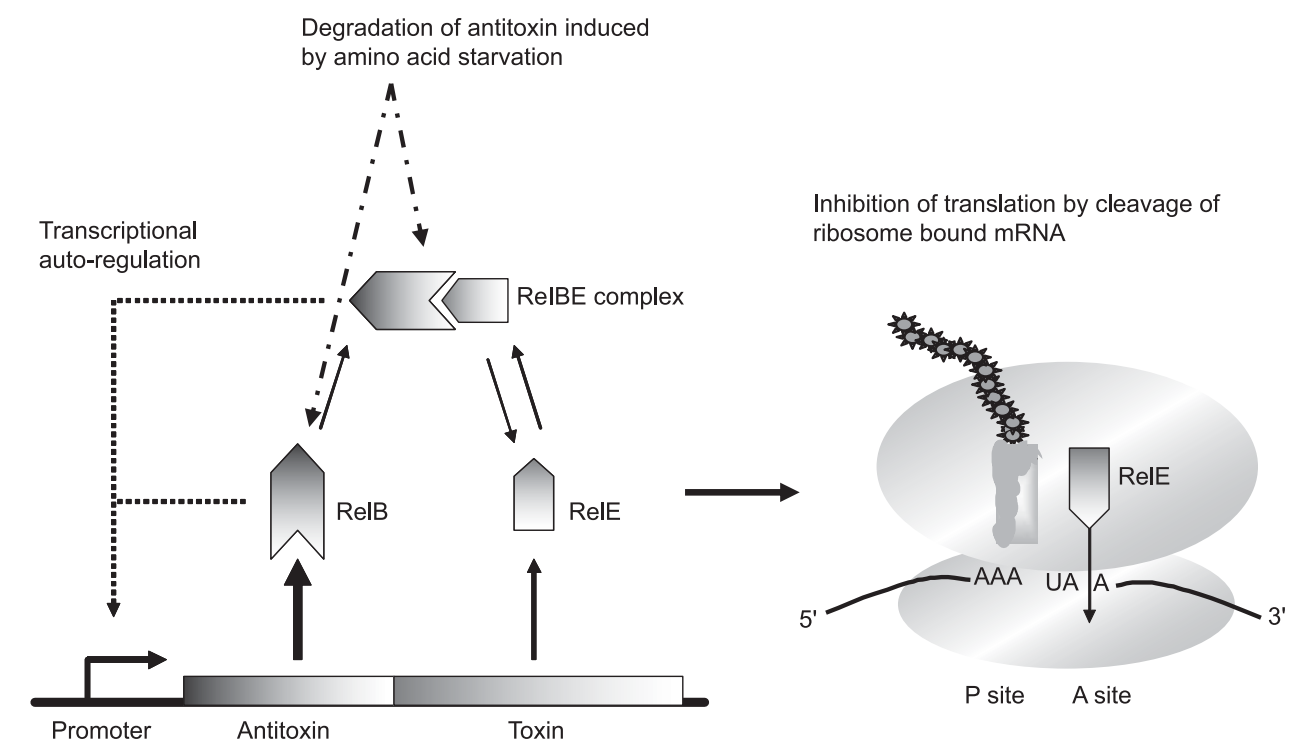

Fig. 1 Genetic organization and regulatory components of the relBE toxin-antitoxin operon (left) and the site of mRNA cleavage by RelE (right).（カラー図は電子ジャーナルhttp://www.jstage.jst.go.jp/browse/biophys/参照)

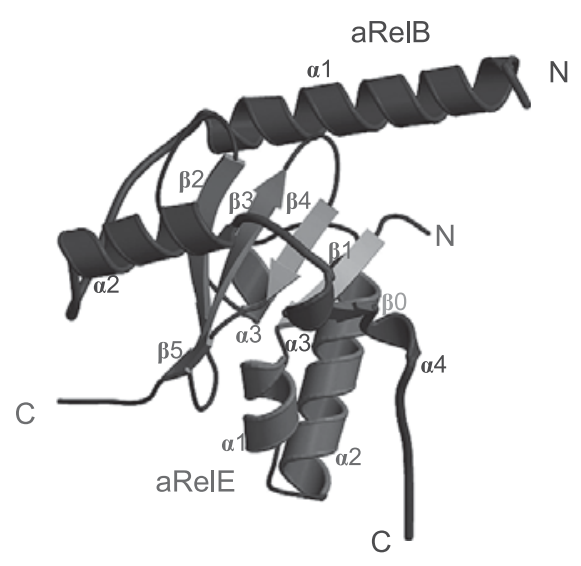

Fig. 2 Structures of aRelB and aRelE. The crystal structure of the complex aRelB/aRelE from P. horikoshii. aRelB is present as a polypeptide chain lacking any distinct hydrophobic core, and aRelE folds into an $\alpha / \beta$ structure. $\mathrm{N}$ and $\mathrm{C}$ indicate $\mathrm{N}$ - and $\mathrm{C}$-termini of both molecules, respectively.（カラー図は電子ジャーナルhttp:// www.jstage.jst.go.jp/browse/biophys/参照)

紹介するとともに, タンパク質合成調節因子である RelE の構造機能相関について概説する.

\section{2. 超好熱古細菌由来タンパク質複合体aRelB- aRelEの結晶構造}

超好熱古細菌aRelB-aRelE複合体の結晶構造を Fig. 2 に示す.アアンチトキシン $\mathrm{aRelB}$ は 3 本の $\alpha$ ヘリックス
からなり，疎水性コアを含まず伸びた構造をもつタン パク質で, aRelEの回りを取り囲むように複合体を形成 していた (Fig. 2). aRelBの伸びた構造は, アンチトキ シンRelBが細胞内プロテアーゼに対して強い感受性を 示すことをよく説明していた，一方，トキシン aRelEは 3 本の $\alpha$ ヘリックスと 5 本の $\beta$ ストランドからなる $\alpha / \beta$ 型の球状タンパク質で, $\alpha$ ヘリックスと $\beta$-シートの疎 水性相互作用により強固な構造をもっていた，aRelBaRelE 複合体の構造は最近決定された MazE-MazF や YoeB-YefM とは類似していなかった. さらに, aRelEの 構造を既知の RNase の構造と比較したが，いずれの RNase とも構造類似性を示さなかった.

次に, 両タンパク質の分子表面の荷電分布を調べて みると, aRelB は全体的に負電荷を帯びているのに対し て, aRelEは正電荷をもち, 両タンパク質の相互作用が 主として静電的相互作用によるものであることがわかっ た. 特に, aRelBの $\alpha 1-\alpha 2$ 間ループに位置する酸性アミ ノ酸クラスター $\left(\mathrm{Glu}^{30}, \mathrm{Glu}^{31}, \mathrm{Asp}^{33}, \mathrm{Asp}^{35}, \mathrm{Glu}^{40}\right)$ が, aRelEの $\beta$-シート上の塩基性アミノ酸クラスター $\left(\mathrm{Lys}^{47}\right.$, $\left.\mathrm{Arg}^{58}, \mathrm{Arg}^{65}, \mathrm{Lys}^{81}, \mathrm{Lys}^{83}\right)$ と静電的に強く相互作用し ていることがわかった.

RNase の阻害様式については, すでにコリシンやバ ルナーゼに打いてよく研究されている.これらの場合, いずれも阻害タンパク質がRNaseの活性部位に結合し 基質の結合を阻止することにより RNase活性を阻害し ている ${ }^{15)}$. 今回決定した aRelB-aRelE は, これら既知 の RNaseに対する阻害形式とは異なり, aRelBが aRelE 


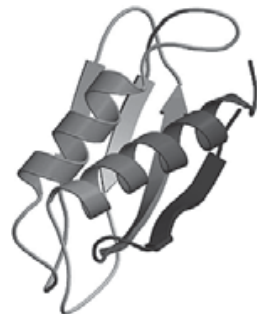

Domain IV in EF-G

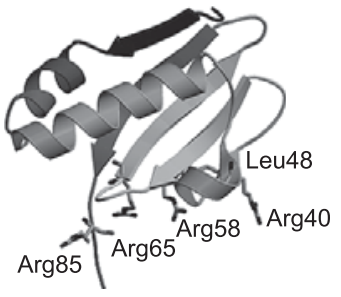

aRelE
Fig. 3 Structural comparison of aRelE with the decoding domain of EF-G. The structure aRelE is compared with that of the decoding domain (domain IV: positions 469-598) in EF-G (PDB: 1DAR). The residues that were shown to be important for protein synthesis inhibitory activity of aRelE are indicated. (カラー図は 電子ジャーナルhttp://www.jstage.jst.go.jp/browse/biophys/ 参照)

の分子表面を取り囲むことにより, aRelEのリボソーム のA-部位への進入を阻害していることが示唆された。

\section{3. aRelEのタンパク質合成阻害活性部位の推定}

aRelEの結晶構造はいずれのRNaseとも構造類似性を 示さなかったが, リボソームの A 部位に tRNAの分子 擬態として作用することが知られている EF-Gのドメイ ンIV と比較したところ，aRelEの分子サイズ，形，お よび二次構造の分布がEF-Gのドメイン IVのそれらに 類似していることがわかった（Fig. 3)。この結果より， aRelEの $\beta 3-\beta 4$ ループと C 末端領域がドメイン IV と同 様にリボソームのA部位に結合することが示唆された.

このことを検証するために, RelEファミリー間でよ く保存されているアミノ酸残基: $\mathrm{Lys}^{13}, \mathrm{Leu}^{18}, \mathrm{Arg}^{40}$, $\mathrm{Leu}^{48}, \mathrm{Gly}^{50}, \mathrm{Arg}^{58}, \mathrm{Arg}^{65}, \mathrm{Lys}^{83}, \mathrm{Arg}^{85}$ をそれぞれAla に置換した 9 種の変異体を作製し，大腸菌無細胞系の タンパク質合成阻害活性に打よぼす影響を調べた (Fig. 4). その結果, $\mathrm{Arg}^{85}$ を Alaに置換した変異体 R85A の阻害活性が著しく低下し, $\mathrm{Arg}^{40}, \mathrm{Leu}^{48}, \mathrm{Arg}^{58}$ 打よび $\mathrm{Arg}^{65}$ をそれぞれ Ala に置換した变異体 R40A，L48A， R58A およびR65A の阻害活性も低下していた。一方, その他のアミノ酸の変異体 K13A, L18A, G50A, K83A はタンパク質合成阻害活性を保持していた。

aRelEのタンパク質合成阻害活性に重要であった5 種 のアミノ酸 $\left(\mathrm{Arg}^{40}, \mathrm{Leu}^{48}, \mathrm{Arg}^{58}, \mathrm{Arg}^{65}, \mathrm{Arg}^{85}\right)$ の高次 構造に打ける位置を見てみると,いずれのアミノ酸残 基も aRelEのリボソームへの結合部位と推定されてい る領域に局在していることから, aRelEが EF-Gのドメ インIVと同様 tRNAの分子擬態としてリボソームのA 部位に結合することが強く示唆された (Fig. 3). 現在,

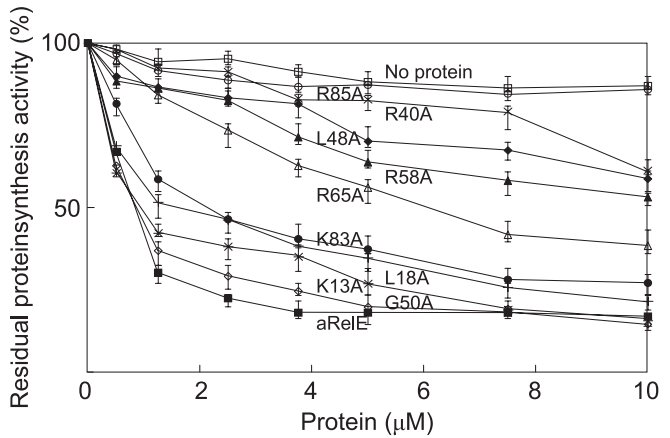

Fig. 4 Protein synthesis inhibitory activity of aRelE and its mutants. Various amounts of aRelE or alanine-substituted mutants were examined as to their potential to inhibit the ${ }^{35} \mathrm{~S}$-methionine incorporation in the $E$. coli ribosomal protein $\mathrm{S} 1$. Inhibition is expressed as the remaining activity of the protein synthesis. The ${ }^{35} \mathrm{~S}-$ methionine incorporation into the ribosomal protein S1 without aRelE or its mutants was set to $100 \%$.

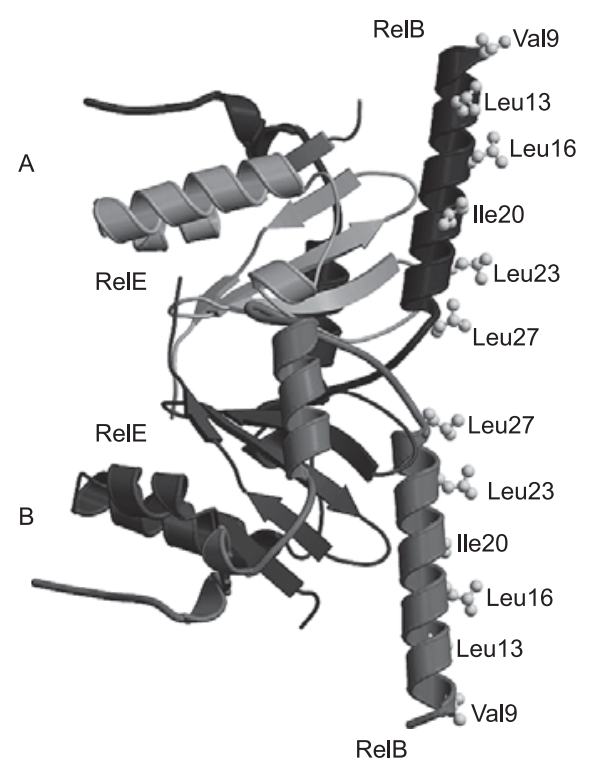

Fig. 5 Heterotetrameric structure of aRelB and aRelE from $P$. horikoshii. Two molecules ( $\mathrm{A}$ and $\mathrm{B}$ ) of the complex aRelB/aRelE observed in the asymmetric unit are indicated. Side-chains of hydrophobic residues at the $\alpha$ helix $\alpha 1$ in aRelB are indicated. (カラー図は電子ジャー ナルhttp://www.jstage.jst.go.jp/browse/biophys/参照)

このことを検証するために, aRelEとリボソーム小サブ ユニットとの複合体の結晶構造解析を, マックスプラ ンク分子遺伝学研究所 (ベルリン) の Willson らとの共 同研究により進めている. 近い将来, RelEの作用機構 が原子レベルで明らかになることを期待している. 


\section{4. aRelB-aRelEのヘテロ4量体構造}

RelB と RelB-RelE 複合体は relBE オペロン上流に位 置する回文塩基配列に結合し, 自らの転写を負に制御 するリプレッサーとしても機能している ${ }^{11}$. 多くのリ プレッサーがホモ 2 量体を形成することにより認識配 列を認識していることから， RelB および RelB-RelE 複 合体の 2 量体化が示唆された. aRelB-aRelEの結晶構造 解析において, 結晶の非対称単位当たり 2 分子の複合 体 (aRelB-aRelE) ${ }_{2}$ が存在したことから，溶液中におい てaRelB と aRelEがへテロ4量体を形成していることが 示唆された. そこで, 複合体 aRelB-aRelEの分子量をゲ ルろ過クロマトグラフィーにより評価したところ, 分 子量約 $35 \mathrm{k}$ に相当する位置に溶出したことから, aRelBaRelE複合体が2量体化していることが強く示唆された.

結晶の非対称単位に見られた $\mathrm{aRelB}$ とRelEのへテ 口 4 量体の構造を Fig. 5 に示す. 興味深いことに $\mathrm{aRelB}$ の $\mathrm{N}$ 末端側の $\alpha$ ヘリックス $(\alpha 1)$ に疎水性アミノ酸 (Leu, Ile, Val）が, ロイシンジッパー様モチーフを形成して 分子表面に露出していることがわかった.ロイシンジッ パーは真核生物の転写因子によく見いだされる構造モ チーフで転写因子の 2 量体化に関与し，その近傍に位 置する塩基性アミノ酸が認識配列との結合に関与して いることが知られている. このことから, aRelBのN末 端 $\alpha$ ヘリックス（ $\alpha 1 ）$ が aRelB および aRelB-aRelE 複 合体の 2 量体化に関与し, $\mathrm{N}$ 末端に位置する塩基性ア ミノ酸Arg2, Lys5, Lys11などが認識配列との相互作 用に関与していることが示唆された。

\section{5. まとめ}

超好熱古細菌 aRelB-aRelE 複合体の結晶構造を解析 し，トキシン RelE の作用様式およびアンチトキシン RelBの阻害様式に関して構造基盤情報を提供した. 既 述したように, RelEが翻訳過程の mRNAをリボソーム 上で特異的に切断することから, RelEはリボソーム依 存性RNase と提唱されている ${ }^{12)}$. 一方, RelE は RNase ではなくリボソームに結合することにより, リボソー ムが本来もっている RNase活性を増強する因子である と提唱している研究グループもある ${ }^{1)}$. 著者らは, aRelE の構造がいずれのRNaseの構造とも類似していないこ とと, aRelBの aRelEに対する阻害様式が既知の RNase
に対するそれと異なることから, RelEの作用機構とし て後者の説を支持している. 今後, aRelB-aRelEの結晶 構造に基づいた生化学的研究と, aRelEとリボソーム小 サブユニットの複合体の結晶構造の解析により, 近い 将来RelEの構造機能相関が解明されることを期待して いる.

最後に, 本稿で紹介した研究成果は, タンパク 3000 プロジェクト個別的解析プログラム「転写・翻訳」の 一環として, 高木久徳君（九大大学院生）と角田佳充 助教授 (九大大学院農学研究院) とともに行ったもの である。また，共同研究者である田中勲教授（北大大 学院理学研究科) と姚閔助手 (北大大学院理学研究科) からは有益な御助言を賜りました. これらの方々にこ の場を借りて厚く感謝申し上げます.

\section{文 献}

1) Buts, L., Lah, J., Dao-Thi, M-H., Wyns, L. and Loris, R. (2005) Trends Biochem. Sci. 30, 672-679.

2) Ogura, T. and Hiraga, S. (1983) Proc. Natl. Acad. Sci. USA 80, 4784-4788.

3) Bernard, P. and Couturier, M. (1992) J. Mol. Biol. 226, 735-745.

4) Masuda, Y., Miyakawa, K., Nishimura, Y. and Ohtsubo, E. (1993) J. Bacteriol. 175, 6850-6856.

5) Zang, Y., Zhang, J., Hoeflich, K. P., Ikura, M., Qing, G. and Inouye, M. (2003) Mol. Cell 12, 913-923.

6) Christensen, S. K., Maenhaut-Michel, G., Mine, N., Gottesman, S., Gerdes, K. and Van Melderen, L. (2004) Mol. Microbiol. 51, 1705-1717.

7) Kamada, K., Hanaoka, F. and Burley, S. K. (2003) Mol. Cell 11, 875-884.

8) Kamada, K. and Hanaoka, F. (2005) Mol. Cell 19, 497509.

9) Gerdes, K. (2000) J. Bacteriol. 182, 561-572.

10) Galvani, C., Terry, J. and Ishiguro, E. E. (2001) J. Bacteriol. 183, 2700-2703.

11) Gotfredsen, M. and Gerdes, K. (1998) Mol. Microbiol. 29, 1065-1076.

12) Pedersen, K., Zavialov, A. V., Paviov, M. Y., Elf, J., Gerdes, K. and Ehrenberg, M. (2003) Cell 112, 131-140.

13) Hayes, C. S. and Sauer, R. T. (2003) Mol. Cell 12, 903911.

14) Takagi, H., Kakuta, Y., Okada, T., Yao, M., Tanaka, I. and Kimura, M. (2005) Nature Struct. Mol. Biol. 12, 327-331.

15) Graille, M., Mora, L., Buckingham, R. H., van Tilbeurgh, H. and Zamaroczy, M. (2004) EMBO J. 23, 1474-1482. 
タンパク質合成抑制因子 RelE とその調節の構造基盤

木村 誠

九州大学大学院農学研究院教授

干 812-8581 福岡市東区箱崎 6-10-1

e-mail: mkimura@agr.kyushu-u.ac.jp 